\title{
Structure elucidation of meroterpenoid habiterpenol, a novel abrogator of bleomycin-induced G2 arrest in Jurkat cells, produced by Phytohabitans suffuscus 3787_5
}

\author{
Ryuji Uchida, Sayaka Yokota and Hiroshi Tomoda
}

A novel abrogator of bleomycin-induced G2 arrest in Jurkat cells, habiterpenol (1), was isolated from the culture broth of Phytohabitans suffuscus 3787_5. The planar structure of 1 was elucidated by spectroscopic study (1D and 2D NMR, MS, UV and IR), and the relative stereochemistry was elucidated by ROESY experiments. Compound 1 belongs to a pentacyclic meroterpenoid having a labdan-type diterpene connecting to an indane moiety.

The Journal of Antibiotics (2014) 67, 783-786; doi:10.1038/ja.2014.71; published online 11 June 2014

\section{INTRODUCTION}

During the course of screening for microbial abrogators of bleomycininduced G2 arrest in Jurkat cells, a new compound, named habiterpenol (1, Figure 1), was isolated from the culture broth of Phytohabitans suffuscus 3787_5. The taxonomy of the producing actinomycete, fermentation, isolation and biological properties of 1 are described in the accompanying paper. ${ }^{1}$ In this study, the physicochemical properties and structure elucidation of 1 are described.

\section{RESULTS}

Physicochemical properties of habiterpenol

The physicochemical properties of habiterpenol (1) are summarized in Table 1. In UV spectra, 1 showed absorption maxima at 221, $234(\mathrm{sh})$ and $284 \mathrm{~nm}$. In IR spectra, broad $\mathrm{OH}$ absorption near $3428 \mathrm{~cm}^{-1}$, typical C-H $\left(\mathrm{CH}_{2}\right)$ stretching absorptions at 2929 and $2851 \mathrm{~cm}^{-1}$ and aromatic C-C stretch absorptions (for carbon-carbon bonds in the aromatic ring) at 1614 and $1461 \mathrm{~cm}^{-1}$ were observed.

\section{Planar structure of habiterpenol}

Compound 1 showed a molecular ion peak at $\mathrm{m} / \mathrm{z} 366[\mathrm{M}]^{+}$in EI-MS, and the molecular formula $\mathrm{C}_{26} \mathrm{H}_{38} \mathrm{O}$ was assigned on the basis of its HR-EIMS $\left(\mathrm{m} / \mathrm{z} 366.2929[\mathrm{M}]^{+}, \Delta+0.6 \mathrm{mmu}\right)$, indicating 8 degrees of unsaturation. The ${ }^{1} \mathrm{H}$ and ${ }^{13} \mathrm{C}$ NMR spectra of 1 in $\mathrm{CDCl}_{3}$ (Table 2) showed 38 proton and 26 carbon signals, which were confirmed by analysis of 2D NMR correlations. The multiplicity of the carbon signals was classified into five methyl carbons, eight $s p^{3}$ methylene carbons, three $s p^{2}$ methine carbons, three $s p^{3}$ methine carbons, two $s p^{2}$ quaternary carbons, four $s p^{3}$ quaternary carbons and one $s p^{2}$ oxygenated quaternary carbon by analysis of DEPT and
HMQC data. The connectivity of proton and carbon atoms was established by HMQC (Table 2). As shown in Figure 2, the partial structures I-V were elucidated by ${ }^{1} \mathrm{H}-{ }^{1} \mathrm{H}$ COSY spectra and TOCSY.

The ${ }^{13} \mathrm{C}-{ }^{1} \mathrm{H}$ long-range couplings of ${ }^{2} J$ and ${ }^{3} J$ in the HMBC spectra (Figure 3) proved the presence of the following linkages: (1) The cross peaks from the $s p^{3}$ methine proton $\mathrm{H}-10\left(\delta\right.$ 0.82) to the $s p^{3}$ quaternary carbon $\mathrm{C}-11(\delta$ 37.4) and the methyl carbon C-18 $\left(\delta\right.$ 16.4), from $s p^{3}$ methylene protons $\mathrm{H}_{2}-13(\delta 1.60,1.40)$ to the $s p^{3}$ quaternary carbon $\mathrm{C}-15(\delta 33.3)$, from the methyl protons $\mathrm{H}_{3}-18$ $(\delta 0.73)$ to the $s p^{3}$ methine carbon C-6 ( $\left.\delta 57.9\right), \mathrm{C}-11$ and the $s p^{3}$ methylene carbon C-12 $(\delta 40.1)$, and from the methyl protons $\mathrm{H}_{3}-19$ $(\delta 0.78)$ and $\mathrm{H}_{3}-20(\delta 0.85)$ to the $s p^{3}$ methine carbon $\mathrm{C}-10(\delta 56.8)$ and the $s p^{3}$ methylene carbon C-14 $(\delta$ 42.2) and C-15 suggested the presence of a 11,15,15-trimethyl-10,11-disubstituted cyclohexane (ring A) containing the partial structure I. (2) Long-range couplings from the $s p^{3}$ methylene protons $\mathrm{H}_{2}-8(\delta 1.82,1.02)$ to the quaternary carbon C-7 $\left(\delta\right.$ 37.4) and C-10, from the methyl protons $\mathrm{H}_{3}-17$ $(\delta 0.33)$ to C-6, C-7 and $s p^{3}$ methylene carbon C-8 $(\delta 43.0)$, and from $\mathrm{H}_{3}-18$ to C-6 showed that a 7,11-dimethyl-6,7,10,11-tetrasubstituted cyclohexane ring (ring $\mathrm{B}$ ) containing the partial structure II is attached to ring $\mathrm{A}$, revealing the presence of a 7,11,15,15-tetramethyl bicyclo[4.4.0] decane moiety. (3) Long-range couplings from the $s p^{3}$ methylene protons $\mathrm{H}_{2}-1(\delta 2.94,2.58)$ to the $s p^{3}$ quaternary carbon C-3 $(\delta 46.3)$, from the $s p^{3}$ methine proton $\mathrm{H}-2(\delta 1.72)$ to C-3, C-7 and the methyl carbon $\mathrm{C}-16(\delta 33.5)$, from the $s p^{3}$ methylene protons $\mathrm{H}_{2}-4(\delta 2.25,1.56)$ to the $s p^{3}$ methine carbon C-2 $(\delta 63.1), \mathrm{C}-3$ and $\mathrm{C}-16$, from the $s p^{3}$ methylene protons $\mathrm{H}_{2}-5(\delta 1.47,1.15)$ to $\mathrm{C}-3$ and C-7, from the methyl protons $\mathrm{H}_{3}-16(\delta 1.06)$ to $\mathrm{C}-2, \mathrm{C}-3$ and the sp3 methylene carbon $\mathrm{C}-4(\delta 34.9)$, and from $\mathrm{H}_{3}-17$ to $\mathrm{C}-2$ showed that a 3,7-dimethyl-2,3,6,7-tetrasubstituted cyclohexane ring (ring C) 


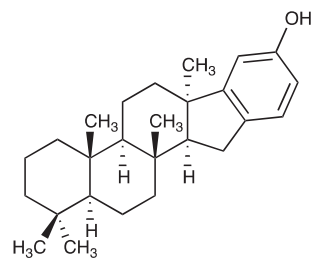

Habiterpenol (1)<smiles>COc1c(C)cc(O)c2c1CC1C3CC[C@H]4[C@@H](C)[C@H](O)CC[C@]4(C)[C@H]3CC[C@]21C</smiles>

Flabellinol<smiles>CC1=CC(=O)C2=C(CC3C4CC[C@H]5C(C)(C)C(O)CC[C@]5(C)C4CC[C@@]23C)C1=O</smiles>

Flabellinone

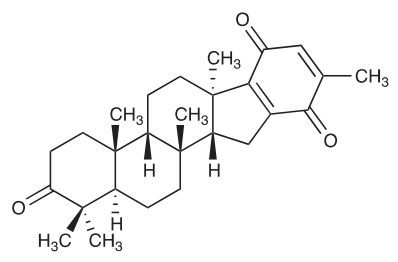

Atomarianone A

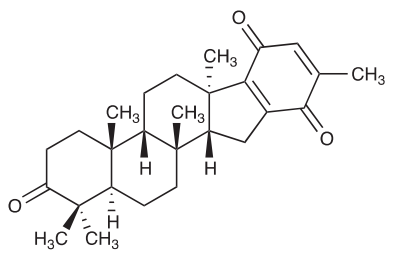

Atomarianone B

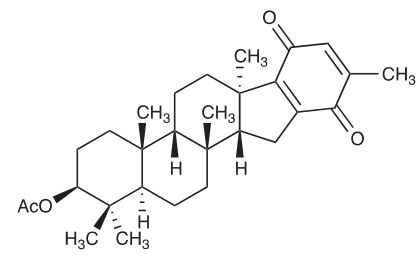

Zonaquinone acetate

Figure 1 Structures of habiterpenol (1) and structurally related compounds.

Table 1 Physicochemical properties of Habiterpenol (1)

\begin{tabular}{|c|c|}
\hline Appearance & Brown powder \\
\hline Molecular weight & 366 \\
\hline Molecular formula & $\mathrm{C}_{26} \mathrm{H}_{38} \mathrm{O}$ \\
\hline \multicolumn{2}{|l|}{ HRFAB-MS } \\
\hline Calcd & $366.2923[\mathrm{M}]^{+}$ \\
\hline Found & $366.2929[\mathrm{M}]^{+}$ \\
\hline $\mathrm{UV} \lambda_{\max } \mathrm{nm}(\varepsilon)$ in $\mathrm{MeOH}$ & 221 (8050), 234 (3290, sh), 284 (3590) \\
\hline $\mathrm{IR} v_{\max } \mathrm{cm}^{-1}(\mathrm{KBr})$ & $\begin{array}{l}3509,3428,2929,2851,1711,1614,1461, \\
1380,1338,1264,1185\end{array}$ \\
\hline$[\alpha]_{D}^{26}$ & $-41.6^{\circ}\left(\mathrm{c} 0.1, \mathrm{CH}_{3} \mathrm{OH}\right)$ \\
\hline \multicolumn{2}{|l|}{ Solubility } \\
\hline Soluble & $\mathrm{CHCl}_{3}, \mathrm{MeOH}$, EtOAc, Acetone \\
\hline Insoluble & Hexane, $\mathrm{H}_{2} \mathrm{O}$ \\
\hline
\end{tabular}

containing the partial structures III and IV is attached to ring B to form a labdane-type diterpene substructure. (4) Long-range couplings from the methine proton $\mathrm{H}-2^{\prime}\left(\delta\right.$ 6.96) to the oxygenated $s p^{2}$ quaternary carbon $\mathrm{C}-4^{\prime}\left(\delta\right.$ 154.2) and the $s p^{2}$ quaternary carbon C-6 ${ }^{\prime}\left(\delta\right.$ 153.8), from the $s p^{2}$ methine proton $\mathrm{H}-3^{\prime}(\delta 6.55)$ to $\mathrm{C}-4^{\prime}$, the $s p^{2}$ methine carbon $\mathrm{C}-5^{\prime}(\delta 107.8)$ and the $s p^{2}$ quaternary carbon $\mathrm{C}-1^{\prime}$ $\left(\delta\right.$ 135.9), and from the $s p^{2}$ methine proton $\mathrm{H}^{\prime} 5^{\prime}(\delta 6.54)$ to the $s p^{2}$ methine carbon C- $3^{\prime}\left(\delta\right.$ 112.6), C- $4^{\prime}$ and C- $6^{\prime}$ showed the presence of a $4^{\prime}$-oxy-1 $1^{\prime}, 6^{\prime}$-disubstituted benzene ring (ring E) containing the partial structure V. Further, the two ortho-coupling constants $(7.5 \mathrm{~Hz})$ observed between aromatic protons $\mathrm{H}-2^{\prime}$ and $\mathrm{H}-3^{\prime}$ also supported that they are in the ortho position of the benzene ring. (5) This benzene ring (ring E) was connected to a labdane-type diterpene moiety by observation of the ${ }^{2} J$ and ${ }^{3} J$ cross peaks from $\mathrm{H}_{2}-1$ to $\mathrm{C}-1^{\prime}$ and the $s p^{2}$ methine carbon $\mathrm{C}-2^{\prime}(\delta 124.6)$, from $\mathrm{H}-2$ to $\mathrm{C}-1^{\prime}$ and C-6 ${ }^{\prime}$, from $\mathrm{H}-2^{\prime}$ to $\mathrm{C}-1$ ( $\left.\delta 30.9\right)$, from $\mathrm{H}-5^{\prime}$ to $\mathrm{C}-3$, and from $\mathrm{H}_{3}-16$ to C- $6^{\prime}$ in $\mathrm{HMBC}$ experiments, indicating the presence of an indane moiety (Figure 3 ). Furthermore, the chemical shifts of C- $4^{\prime}$ ( $\delta$ 154.2) indicated that a hydroxyl group is attached to C- $4^{\prime}$. Taking these observations into consideration, the planar structure of $\mathbf{1}$ was elucidated as shown in Figure 1, which fulfilled the molecular formula and the degrees of unsaturation.

\section{Relative stereochemistry of habiterpenol}

Compound 1 has six chiral carbons. The relative stereochemistry of 1 was elucidated by analysis of ROESY experiments as shown in Figure 4. NOEs were observed between $\mathrm{H}_{3}-18(\delta 0.73)$ and $\mathrm{H}_{3}-19$ $(\delta 0.78)$, between $\mathrm{H}_{\mathrm{ax}}-13(\delta 1.60)$ and $\mathrm{H}_{3}-19$ and between $\mathrm{H}_{\mathrm{ax}}-13$ and $\mathrm{H}_{3}-18$, indicating that they are all oriented to the same molecular face. On the other hand, NOEs were observed between H-10 $(\delta 0.82)$ and $\mathrm{H}_{\mathrm{ax}}-14(\delta 1.15)$ and between $\mathrm{H}_{\mathrm{ax}}-12(\delta 0.84)$ and $\mathrm{H}_{\mathrm{ax}}-14$, indicating that they are all oriented to the opposite molecular face. These results strongly suggested trans-diaxal disposition of $\mathrm{H}-10$ and $\mathrm{H}_{3}-18$. NOEs were also observed between $\mathrm{H}_{\mathrm{ax}}-9\left(\begin{array}{ll}\delta & 1.26\end{array}\right)$ and $\mathrm{H}_{3}-17\left(\begin{array}{ll}\delta & 0.33\end{array}\right)$, between $\mathrm{H}_{\mathrm{ax}}-9$ and $\mathrm{H}_{3}-18$ and between $\mathrm{H}_{3}-17$ and $\mathrm{H}_{3}-18$, indicating that they are all oriented to the same molecular face. On the other hand, NOEs were observed between $\mathrm{H}-6(\delta 0.85)$ and $\mathrm{H}_{\mathrm{ax}}-8\left(\begin{array}{l}\delta \\ 1.02\end{array}\right)$ and between $\mathrm{H}_{\mathrm{ax}}-8$ and $\mathrm{H}-10$, indicating that they are all oriented to the opposite molecular face. These data were consistent with trans disposition of $\mathrm{H}-6$ and $\mathrm{H}_{3}-17$. Furthermore, NOEs were observed between $\mathrm{H}-2\left(\delta\right.$ 1.72) and $\mathrm{H}-6$, between $\mathrm{H}-2$ and $\mathrm{H}_{3}-16(\delta$ 1.06) and between $\mathrm{H}_{3}-17$ and $\mathrm{H}_{\mathrm{eq}^{-1}}(\delta 2.58)$, indicating that the $\mathrm{C} / \mathrm{D}$ ring junction is cis. This cis junction was also supported by the fact that the chemical shift of methyl proton $\mathrm{H}_{3}-17$ was shifted upfield due to the anisotropic effect of the hydroxyphenyl group. Taken together, these findings suggested that $\mathbf{1}$ has a trans-transoid-trans-transoid-cis 
Table $2{ }^{1} \mathrm{H}$ and ${ }^{13} \mathrm{C}$ NMR chemical shifts of habiterpenol (1) in $\mathrm{CDCl}_{3}$

\begin{tabular}{|c|c|c|c|c|c|}
\hline Position & $\delta_{C}{ }^{a}$ & Mult. & $\delta_{H}^{\mathrm{b}}$ & Mult. & $\mathrm{J}(H z)$ \\
\hline \multirow[t]{2}{*}{1} & 30.9 & $\mathrm{t}$ & 2.94 & ddd & $16.0,7.0,1.0$ \\
\hline & & & 2.58 & $\mathrm{~d}$ & 16.0 \\
\hline 2 & 63.1 & $d$ & 1.72 & br. d & 7.0 \\
\hline 3 & 46.3 & s & & & \\
\hline \multirow[t]{2}{*}{4} & 34.9 & $\mathrm{t}$ & 2.25 & dt & $14.0,4.0$ \\
\hline & & & 1.56 & $\mathrm{~m}$ & \\
\hline \multirow[t]{2}{*}{5} & 18.2 & $\mathrm{t}$ & 1.47 & $\mathrm{~m}$ & \\
\hline & & & 1.15 & $\mathrm{~m}$ & \\
\hline 6 & 57.9 & d & 0.85 & $\mathrm{~s}$ & \\
\hline 7 & 37.4 & $s^{c}$ & & & \\
\hline \multirow[t]{2}{*}{8} & 43.0 & $\mathrm{t}$ & 1.82 & $\mathrm{dt}$ & 13.0, 3.0 \\
\hline & & & 1.02 & $\mathrm{dt}$ & $13.0,4.0$ \\
\hline \multirow[t]{2}{*}{9} & 18.4 & $\mathrm{t}$ & 1.47 & $\mathrm{~m}$ & \\
\hline & & & 1.26 & $\mathrm{~m}$ & \\
\hline 10 & 56.8 & $\mathrm{~d}$ & 0.82 & $\mathrm{~m}$ & \\
\hline 11 & 37.4 & $s^{c}$ & & & \\
\hline \multirow[t]{2}{*}{12} & 40.1 & $\mathrm{t}$ & 1.72 & $\mathrm{~m}$ & \\
\hline & & & 0.84 & $\mathrm{dt}$ & $11.5,2.5$ \\
\hline \multirow[t]{2}{*}{13} & 18.6 & $\mathrm{t}$ & 1.60 & $\mathrm{~m}$ & \\
\hline & & & 1.40 & $\mathrm{~m}$ & \\
\hline \multirow[t]{2}{*}{14} & 42.2 & $t$ & 1.36 & $\mathrm{~m}$ & \\
\hline & & & 1.15 & $\mathrm{~m}$ & \\
\hline 15 & 33.3 & $\mathrm{~s}$ & & & \\
\hline 16 & 33.5 & $q$ & 1.06 & $3 \mathrm{H}, \mathrm{s}$ & \\
\hline 17 & 16.43 & $q^{d}$ & 0.33 & $3 \mathrm{H}, \mathrm{s}$ & \\
\hline 18 & 16.42 & $q^{d}$ & 0.73 & $3 \mathrm{H}, \mathrm{s}$ & \\
\hline 19 & 21.5 & $q$ & 0.78 & $3 \mathrm{H}, \mathrm{s}$ & \\
\hline 20 & 33.4 & q & 0.85 & $3 \mathrm{H}, \mathrm{s}$ & \\
\hline $1^{\prime}$ & 135.9 & s & & & \\
\hline $2^{\prime}$ & 124.6 & d & 6.96 & br. d & 7.5 \\
\hline 3' & 112.6 & d & 6.55 & dd & $7.5,2.5$ \\
\hline $4^{\prime}$ & 154.2 & s & & & \\
\hline $5^{\prime}$ & 107.8 & $d$ & 6.54 & s & \\
\hline $6^{\prime}$ & 153.8 & s & & & \\
\hline 4'-OH & & & 4.67 & br. $\mathrm{s}$ & \\
\hline
\end{tabular}

${ }^{a 13} \mathrm{C}$ chemical shifts are shown in $\delta$ values (p.p.m.) relative to $\mathrm{CDCl}_{3}$ at 77.0 p.p.m. 1 $\mathrm{H}$ chemical shifts are shown in $\delta$ values (p.p.m.) relative to $\mathrm{CDCl}_{3}$ at 7.26 p.p.m. followed by multiplicity and coupling constants $(\mathrm{J} \mathrm{Hz})$.

${ }^{c}$ Overlapped by other signals (assignment based on HMQC experiments).

dExchangeable signals.

arrangement for the $\mathrm{A}-\mathrm{B}-\mathrm{C}-\mathrm{D}$ ring system. Thus, the relative stereochemistry of 1 was presumed to be $2 S^{\star} 3 R^{\star} 6 R^{\star} 7 R^{\star} 10 S^{\star} 11 S^{\star}$.

\section{DISCUSSION}

In the course of screening for microbial abrogators of bleomycininduced G2 arrest in Jurkat cells, habiterpenol (1, Figure 1) was isolated from the culture broth of $P$. suffuscus 3787 5..$^{1}$ In this study, the structure of 1 was elucidated to be a meroditerpenoid with a labdane-type diterpene connecting an indan moiety. A number of meroditerpenes having a benzofuro- or benzopyrano-ring moiety were isolated from natural sources, but five kinds of indan like moiety-containing meroterpenoids including 1 (Figure 1) have been reported so far. Sabry et al. ${ }^{2}$ isolated flabellinol and flabellinone from Stypopodium flabelliforme as potent inhibitors of the sodium channel. Abatis et al. ${ }^{3}$ isolated atomarianones A and B from Taonia atomari as cytotoxic agents in two lung cancer cell lines. Penicooke et al. ${ }^{4}$ isolated zonaquinone acetate from $S$. zonale as a cytotoxic agent in<smiles>CCCCC</smiles>

II<smiles>CCCCC</smiles>

IV

V<smiles>CC=CC</smiles>

Figure 2 Partial structures of 1 elucidated by ${ }^{1} \mathrm{H}-{ }^{1} \mathrm{H}$ COSY and TOCSY

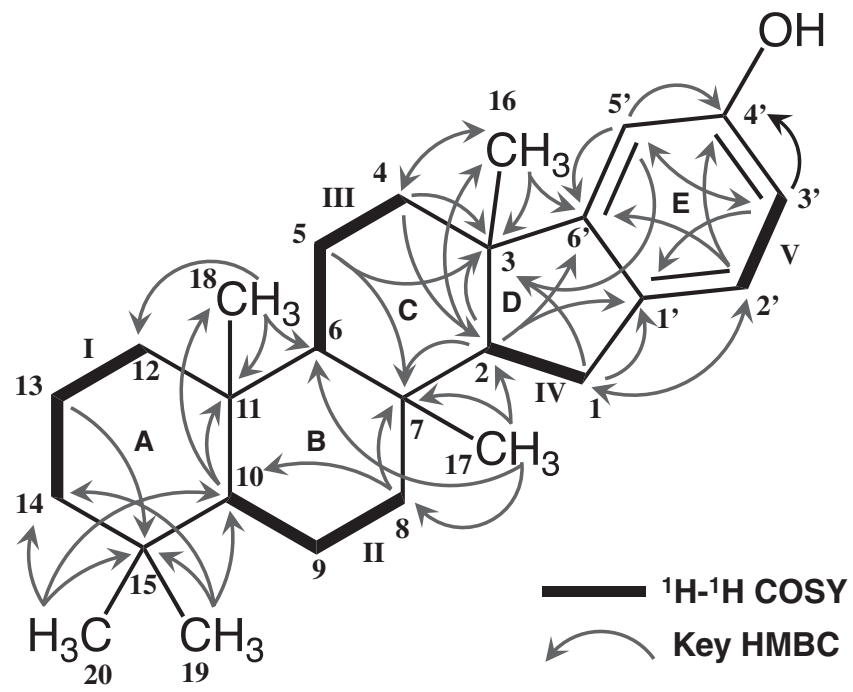

Figure 3 Planar structure of 1 elucidated by HMBC experiments.

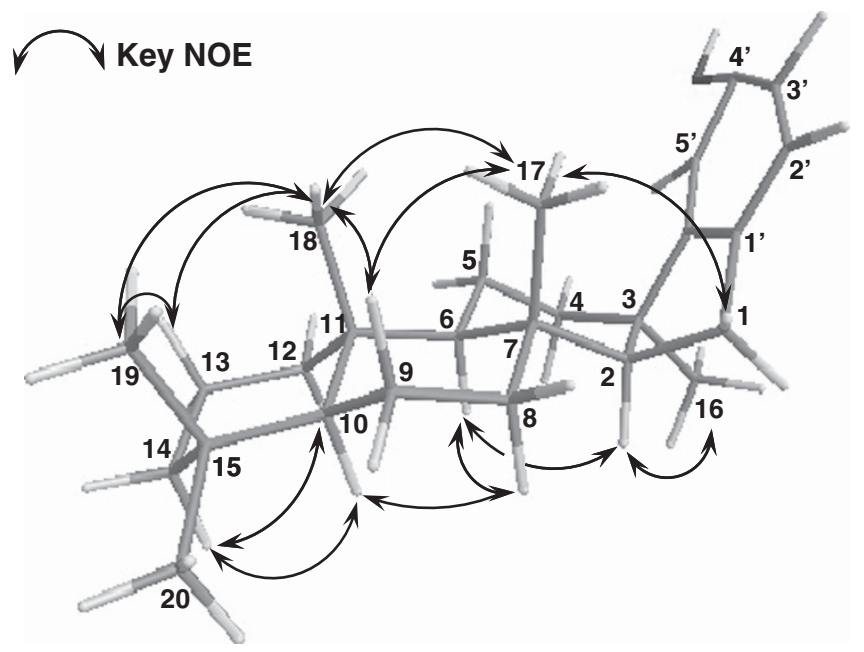

Figure 4 Relative configuration of 1 elucidated by NOE experiments. A full color version of this figure is available at The Journal of Antibiotics journal online.

breast cancer and colon cancer cell lines. Interestingly, these meroditerpenoids were isolated from marine algae, while $\mathbf{1}$ was isolated from an actinomycete. The stereochemistries of these five 
meroditerpenoids differed as follows (Figure 1). Flabellinol and flabellinone have a unique cis-cisoid-cis-cisoid-trans A-B-C-D ring structure that induces rings $\mathrm{A}$ and $\mathrm{C}$ into chair conformations and ring $\mathrm{B}$ into a twist boat. ${ }^{2}$ Atomarianone $\mathrm{A}$ and zonaquinone acetate have an unprecedented trans-cisoid-cis-cisoid-trans A-B-C-D ring structure, while atomarianone $\mathrm{B}$ is the epimer of atomarianone $\mathrm{A}$ at $\mathrm{C}-7$ constructing a trans-cisoid-trans-transoid-trans $\mathrm{A}-\mathrm{B}-\mathrm{C}-\mathrm{D}$ ring structure. ${ }^{3}$ As elucidated in this study, 1 has a trans-transoidtrans-transoid-cis $\mathrm{A}-\mathrm{B}-\mathrm{C}-\mathrm{D}$ ring structure that induces rings $\mathrm{A}, \mathrm{B}$ and $\mathrm{C}$ into chair conformations; therefore, $\mathbf{1}$ has a unique ring structure among diterpens fused with an indane moiety in natural products. Further experiments, for example, X-ray crystallography or total synthesis, are needed to confirm the absolute stereochemistry of $\mathbf{1}$.

\section{METHODS}

\section{General}

Various NMR spectra were obtained using an Agilent Technologies XL-400 $(400 \mathrm{MHz})$ spectrometer (Agilent Technologies, Santa Clara, CA, USA). Electrospray ionization mass spectrometry (ESI-MS) was conducted on a JEOL JMS-T100LP spectrometer (Tokyo, Japan). UV-visible and IR spectra were measured with a Beckman DU640 spectrophotometer (Beckman Coulter, Inc., Fullerton, CA, USA) and a Horiba FT-210 Fourier transform infrared spectrometer (Horiba, Kyoto, Japan), respectively. Optical rotations was recorded on a JASCO model DIP-181 polarimeter (JASCO, Tokyo, Japan).

\section{Producing actinomycete $P$. suffuscus 3787_5 and isolation of habiterpenol}

The fermentation and purification procedures of 1 were described in the accompanying paper. $^{1}$ The habiterpenol-producing actinomyces $P$. suffuscus 3787_5 was isolated from a soil sample collected on Ishigaki Island, Japan. Bioassay-guided fractionation of the culture broth of the actinomycete, including organic solvent extraction, ODS gel column chromatography and reversed phase (C4) HPLC, yielded 1.

\section{ACKNOWLEDGEMENTS}

We express our thanks to Ms N Sato and Dr K Nagai, School of Pharmacy, Kitasato University, for measurements of NMR and mass spectra.

1 Uchida, R. et al. Habiterpenol, a novel abrogator of bleomycin-induced G2 arrest in Jurkat cells, produced by Phytohabitans suffuscus 3787_5. J. Antibiot. 67, 777-781 (2014)

2 Sabry, O. M. et al. Neurotoxic meroditerpenoids from the tropical marine brown alga Stypopodium flabelliforme. J. Nat. Prod. 68, 1022-1030 (2005).

3 Abatis, D. et al. Atomarianones A and B: two cytotoxic meroditerpenes from the brown alga Taonia atomaria. Tetrahedron Lett. 46, 8525-8529 (2005).

4 Penicooke, N. et al. Antiproliferative activity and absolute configuration of zonaquinone acetate from the Jamaican alga Stypopodium zonale. Phytochemistry 87, 96-101 (2013).

Supplementary Information accompanies the paper on The Journal of Antibiotics website (http://www.nature.com/ja) 